\title{
The existence of nursing in caring for terminally ills'life: a phenomenological study*
}

\author{
O EXISTIR DA ENFERMAGEM CUIDANDO NA TERMINALIDADE DA VIDA: UM ESTUDO \\ FENOMENOLÓGICO
}

\section{EL EXISTIR DE LA ENFERMERÍA EN EL PROCESO DE CUIDADO EN EL TÉRMINO DE LA VIDA: UN ESTUDIO FENOMENOLÓGICO}

\author{
Carla Simone Leite de Almeida', Catarina Aparecida Sales ${ }^{2}$, Sônia Silva Marcon ${ }^{3}$
}

\begin{abstract}
By taking care of cancer patients in their process of end of life, nursing experience situations of suffering before the anguish of others. This study aimed to understand the meaning and significance attributed by the nurses from the palliative care cancer hospital. This is a phenomenological research, grounded in Heidegger's thinking, performed with 13 nurses, who work at Oncology hospitalward, through semi-structured interviews, which were analyzed according to the steps recommended by Josgrilberg. From understanding the statementsof the subjects, two ontological themesemerged: Feeling satisfaction and love in the care offered and Feeling anger and inabilitytowards terminally ill patients. We inferred that working in Oncology Ward is something rewarding for these professionals, but it entails physical and mental suffering, from feeling helpless before the death-dying process. Thus, we showedthat nursing professionals need to be recognized as human beings and as such, also deserving of care.
\end{abstract}

\section{DESCRIPTORS}

Palliative care

Oncologic nursing

Holistic nursing

Humanization of assistance

\section{RESUMO}

Ao cuidar do paciente oncológico em seu processo de terminalidade de vida, a enfermagem experiencia as situações de sofrimento ante a angústia do outro. Este estudo teve como objetivo compreender o sentido e o significado atribuídos, pelos profissionais de enfermagem, ao cuidado paliativo oncológico hospitalar. Trata-se de uma pesquisa fenomenológica, embasada no pensar heideggeriano, realizada com 13 profissionais de enfermagem, atuantes em Ala Oncológica hospitalar, por meio de entrevistas semiestruturadas, que foram analisadas, segundo os passos preconizados por Josgrilberg. Da compreensão da linguagem dos sujeitos, emergiram duas temáticas ontológicas: Sentindo satisfação e amor no cuidado ofertado e Sentindo revolta e impotência frente à terminalidade. Depreendemos que trabalhar em Ala Oncológica é algo gratificante para esses profissionais, mas acarreta sofrimento físico e mental, proveniente de sentir-se impotente ante ao processo morte-morrer. Assim, evidenciamos que os profissionais da enfermagem necessitam ser reconhecidos como seres humanos e, como tais, também merecedores de cuidados.

\section{DESCRITORES \\ Cuidados paliativos \\ Enfermagem oncológica \\ Enfermagem holística \\ Humanização da assistência}

\section{RESUMEN}

Durante el transcurso del cuidado de un paciente oncológico en el proceso de término de su vida, el profesional de enfermería experimenta situaciones de sufrimiento ante la angustia del otro. Este estudio buscó comprender el sentido y el significado atribuido, por los profesionales de enfermería, al cuidado paliativo oncológico hospitalario. Se trata de una investigación fenomenológica basada en el pensar heideggeriano, realizada con 13 profesionales de enfermería de un servicio hospitalario oncológico por medio de entrevistas semi-estructuradas, posteriormente analizadas según los pasos preconizados por Josgrilberg. De la comprensión del lenguaje de los participantes, surgieron dos temáticas ontológicas: Sintiendo satisfacción y amor en el cuidado ofrecido y Sintiendo indignación e impotencia frente al término de la vida. Se infiere que trabajar en un servicio oncológico es gratificante para estos profesionales, pero trae sufrimiento físico y mental por sentirse impotente ante el proceso muerte-morir. Así, se demuestra que los profesionales de enfermería deben ser reconocidos como seres humanos y como tales, también merecedores de cuidado.

\author{
DESCRIPTORES \\ Cuidados paliativos \\ Enfermería oncológica \\ Enfermería holística \\ Humanización de la atención
}

\footnotetext{
* Extracted from the dissertation "A vivência existencial dos profissionais de enfermagem no cuidado paliativo hospitalar oncológico.", State University of Maringa, 2011. ${ }^{1} \mathrm{PhD}$ candidate in Nursing, State University of Maringa, Maringa, PR, Brazil. ${ }^{2}$ Associate Professor of Undergraduate and Graduate Nursing courses, State University of Maringa, Maringa, PR, Brazil. catasales@hotmail.com ${ }^{3}$ Associate Professor of Undergraduate and Graduate Nursing courses, State University of Maringa, Maringa, PR, Brazil.
}

$\begin{aligned} \text { Rev Esc Enferm USP } & \text { Received: } 08 / 06 / 2013 \\ \text { 2014; 48(1):34-40 } & \text { Approved: } 12 / 12 / 2013\end{aligned}$




\section{INTRODUCTION}

Since the early days of nursing, care for human beings is the essence of the profession, whose work force emanates in favor of life, performing tasks aimed at curing illness and rehabilitation of health. However, as health professionals, we face the rescue of life and also death situations and the need to accept this as a natural process in the life cycle ${ }^{(1)}$.

Palliative care is a highly specialized approach to helping people with cancer and their families to live and face death as best as possible. Since 1990, the World Health Organization $(\mathrm{WHO})^{(2)}$ adopted the philosophy of palliative care $(P C)$ as a humanized therapeutic care of patients whose disease is not responsive to curative treatment, especially when the disease is in an advanced and progressivestage $\mathrm{e}^{(3)}$.

The PC can be performed in different contexts, such as at home, in general health institutions where the patient is hospitalized, in a specific unit within the health institution dedicated exclusively for this purpose, and even in social institutions which care for patients with anticancer treatment ${ }^{(4)}$. PC aims to promote the quality of life of the patient's days without therapeutic possibilities through pain relief and the biological, psychological and spiritual suffering ${ }^{(2)}$. Although PC constitutes a therapeutic modality to be employed since the diagnosis of a chronic degenerative disease, such as cancer, it is currently used only when traditional medicine fails to rescue the patient's life.

The nursing staff is directly involved in the treatment process and it is present at the end of life, and shall assist the patient without therapeutic possibilities and family. By taking care of cancer patients, nurse practitioners experience situations of suffering, anguish, fear, pain and angst lived by patients and their families and as human beings with emotions and feelings, at times manifest the same reactions ${ }^{(5)}$.

This position was reiterated in a study to assess the impact of care to cancerpatients by nursing staff who asserts that care professionals are not prepared to deal daily with human weaknesses in relation to life and death, which creates suffering and anxiety ${ }^{(6)}$. This is a reality not only in the Brazilian scenario, but also veteran countries in the implementation of palliation ${ }^{(7-8)}$.

In our experiences as nurses and nurse professors, we live with death situations when we monitor students in undergraduate nursing Oncology Ward of general hospitals. We realize the paradox experienced by nursing staff who, on one hand, is relieved by the end of the suffering of the patient and, secondly, angst given the pain that death brings. In patient care outside of therapeutic possibilities and their families, nurse practitioners are Influenced by their conceptions, values and experiences in relation to death and dying and, in this situation, they need to work on their emotions ${ }^{(9)}$.
Assuming that carerequires the triad patient-familyprofessional, the action of care must come from those who care, but professionalsmust also be cared for. The design of the present study led us to seek the understanding of the phenomenon: How do these professionals feelwhen they perform PC in the hospital? How is the terminally ill situation experienced by them? The purpose of this study was to understand the meaning and significance attributed by the nursing staff of the oncology hospital in relation to the practice of palliation.

In our view, research on this scope are justified, since, for the year 2013, there wereestimates which indicate the occurrence of approximately 518.510 new cases of cancer $^{(10)}$. This reality shows that health professionals, especially nurses, will have to increasingly provide care for people with cancer and their families. In these moments of care, the nursing staff undergoes emotional distress when faced with situations arising from the disease. This requires understanding of how these professionals experience the care, which includes the identification of their biopsychosocial needs, which must be taken into account in the planning of health activities and programs geared to such professionals.

\section{METHOD}

In seeking to answerour concerns, we chose qualitative research, in Heidegger's existential phenomenological approach. Heidegger's phenomenology ${ }^{(11)}$ have shown an ontological sense, because it focuses on the question of Being. The essence (eidos) of man lies in his existence and only through the existence of an entity, it is possible to go towards the Being with the aim of finding his/her mysteries. It provides nursing professionals to make sense of their experiences and activities, making it more reflective and aware of the reality and the way of being of others ${ }^{(12)}$.

Considering these aspects, we envisionedthe phenomenological approach to understanding the nursing possibility of their existence in the care of the patient with cancer without healing prognosis, ie, through their existence, embracing their existential dimensions of human being who cares. Thus, the region or ontological investigation is the situation in which we seek to unveil the phenomenon occurs - the latent subjectivity in the experiences of nurses as beings of care, from the oncology ward of a general hospital of medium size, located in the region Midwest State of Parana.

Research subjects were 14 nursing professionals. The inclusion criteria were:to be working in the Oncology Ward of the hospital and to bepart of the category of assistance nurse, nurse technician or nurse. Exclusion criteria were:subjects who were absent from the workplace in the collection data period, because of medical leaveor vacation. One of the professionals refused to participate in the study, which resulted in 13 participants. 
Data were collected between the months of March to May 2011, through a recorded interview, guided by the question: What do you feel when you provide palliative care to oncology patients? Also, notes were taken in a field diary. Subsequently, the interviews were transcribed in fulland each speech was analyzed individually ${ }^{(13)}$. A priori, we performed acarefulreading of each statement, separating quotesor unit senses (us) that proved to be fundamental structures of existence. After that, we analyze the units of meaning of each statement, performing a phenomenological selection of statements from each subject, as a unit of meaning, in general, consists of feelings revealed by the participants that consider a ontological question. Finally, we highlight the senses that wereunveiled in every discourse, from thoseemerged the followingontological thematic: Feeling satisfaction and love in the care offered and feeling anger and inabilitytowards terminally ill patients, which were interpreted in the light of Heidegger's perspective and from authors who researchfor palliation.

To maintain anonymity, the participantswere given pseudonyms of stars, because they are celestial bodies that provide guidance for many navigatorsand having a peculiar sparkling, radiant glow that gives beauty to heaven even in dark nights ${ }^{(14)}$. This is because we consider that the brightness of nursing in caring existenceprovideguidance and support to many cancer patients and their families during their hospital stay and that even in difficult times, like death, nurses do not let them withoutshine.

The interviews were recorded and transcribed, also stored electronically. The development of the study complied with ethical aspects, guided by Resolution 196/96, and was approved by theEthicsCommittee of Human Research, State University of Maringa, under protocol number 709/2010.

\section{RESULTS}

\section{Feeling satisfaction and love in the care offered}

Nursing professionals, in order to develop actions of daily care, feel satisfaction in working in hospital oncology ward, enjoying the feeling of professional achievement in the care offered, showing compassion to the patient in his dying being.

It gives us satisfaction to see that the patient is not suffering, providing the least we can so that he/she can suffer lesswhen we cannot interfere, or to be somehow helping him/her in his/her last days of life (Procyon).

(...)when I can apply some type of palliative care for the patient and I realize that it was important and that it contributed so that the patient could be more comforted, calmer, I don't feel gratified, I feel satisfied (Vega)

I'm happy and sad to learn that the family is going through this, but I feel happy. I believe that I'mdoing everything I can to ease the pain ofterminal ill patientsin palliative state. I give them my all and it is very comforting (Hadar).

In building the care of the patient hospitalized and without possibility of cure, the professionals experience feelings of achievement, accomplishment and satisfaction to see the results of their work through the recognition expressed by the patient with cancer and their families. These feelings motivate the nursing team to continue exercising the art of care.

I feel happy to be able to help people. Frequently, they even say: How nice to have someone to listen to me, listen to my problem and who really understands me (Capella).

I feel a very rewarding feeling, especially here (in oncology ward) they thank you and you have a lot of contact because any act you do, they thank you. Viewing the patient's situation, I feel accomplished as a professional and being able to help (Aldebaran).

The bond of nursing care is given through love that is felt by the profession, and to act in palliative care to the being ill with cancer, which demonstrates that without this component, it is difficult to implement a humanized care.

(...)I care for love, not for money. I think l'mon the right track, at the right place. So I want to go deeper, take a course, attend a lecture about it (Barnard).

(...)l love this profession. Here,you see a lot of suffering, it is a test. I think everyone who is a nurse had to go through the oncology to see if they will really love this profession (Régulus).

Nurse practitioners feel gratification, joy and satisfaction when performingpalliative care, and temper their daysat work with love and passion, overcoming patient-nurse barrier, perpetuating the contact between humans.

(...)you go home and then you wonder. There is no way you can go home and forget everything. There is just no way, you end up getting involved, we try to avoid this involvement, but we end up getting involved (RiguelKentourus).

Well ... I arrive home and I pray a lot, we know that when we leave a shift, we leave the patient in a situation and when we come back it is possible the patient won't be there anymore (...)(Luyten).

\section{Feeling anger and inability towards terminally ill patients}

Facing the situation of death experienced by cancer patients without cure prognostics, nursing professionals unveil feelings of anguish, frustration and suffering, which are expressed as consequences of their choices, because they feel powerless and unprepared to care in terminality.

When you see a person dying and we can't do anything it's a shock to me, but I think ... I wanted this work, so I have to endure. I know this happens, and it happens here every day, but it is outside the realm of what we learn and see in the classroom (Antares).
The existence of nursing in caring for terminally ills'life: a phenomenological study Almeida CSL, Sales CA, Marcon SS 
I'm just unsure what to do, sometimes I think I chose thewrong profession, that it wasn't supposed to be this profession, because many times, honestly, I do not know what to do (...) One minute you think you are doing everything wrong, other time you think you are doing everything right. This ends up making a mess in my head (Betelgeuse).

The unpreparedness given terminally ill patients, evidenced by the participants, causes the death to become a daunting, dreaded and uncomfortable question in the daily lives of these professionals, provoking deep inside feelings of denial, anger, sadness and anxiety.

(...)sometimes we have to ignore that he is a terminal ill patient. I care for him with the intention that he will survive and get better (...) I ignore that he will die, because I want him to get better, he will be cured (emotion) (Centauri).

(...) when the time comes and you cannot resuscitate, I am unsure what to do and I cannot even want to go over these rules (do not resuscitate) (...) I have not studied to see someone dying, you come to save lives, to help, not to be on time and look at our colleagues on the side and say we lost the patient (...) when it happens I leave devastated, I leave as if I had lost that day during that hour there, (...) (Tau ceti).

I think: Why do humans have to go through this? I feel so useless and think: What am I doing here? (Betelgeuse).

Apart from the stress and suffering that terminally ill patients causes within nursing professionals, it also generates professional indifference in caring for the sick in their being to death as a defense mechanism to keep nurses mentally healthy.

I do not feel well (...) It is not an easy thing to be doing, seeing the person there in bed, knowing he can die at any moment, and that there isn'tanything else to do. So I try not to have much contact, not to get too attached to the patient, because then who ends up suffering is us (Wolf).

\section{DISCUSSION}

In Heidegger's analytic ${ }^{(11)}$, the term existence does not mean reality or what is in the world, as the existence of a tree or a stone. The existence, the way it is treated in Being and Time, comes from the verb ex-sistere, ek-sistence and is understood as that which emerges, unveiling, projectingbeyond themselves, discovering their own sense and opening themselvesto the world. Existence is a, uninterruptedly,coming out or being out in the opennessofitself ${ }^{(15)}$. And it is this openness that being a nurse can express concern actions to accomplish care to cancer patients.

Existentially, being-there, in its being-in-world live in constant relationship with other entities belonging to the world. Care emerges from this relationship because being-in-the-world is essentially ensuring, caring, being interested, and existingbeside things and other beings and being-with-others in the world. In Heidegger's analy- sis, this relationship is called concern and relate to each other is the fundamental structure of being-there ${ }^{(11)}$.

Afterbeing thrown into the world, the being-there exists in a situation of ambiguity, ie, he/she is free to make his/her choices, but it is also circumstantial. In this condition, the human being lives in a continuing situation of choices, to take risks and take on the implications of their decisions ${ }^{(16)}$. And those choices may indicate the freedom of being a nurse in being-with-others authentically.

The participants expressed feelings of joy, satisfaction, empathy, love and mainly concern for each other. These feelings constitute a genuine care and are fundamental ingredientsto the philosophy practice of palliative care, for palliation in cancer, and to recognize the biopsychosocial and spiritual needs of the patient and his/her family, nurse practitioners must have respect, love, empathy, to deal with issues of finitude and collaborate to transcendence of the patient, family and themselves ${ }^{(17)}$.

A study conducted with nurses and family relatives in an oncology wardof Hong Kong supports the thinking of our participants, when they mention that to take care of a patient without therapeutic possibility, the professional needs to know how to listen, act, relate, communicate, have empathy, respect, sensitivity and authenticity to get to work with terminally ill patients and promote personal growth of the patient, family and himself/herself ${ }^{(18)}$.

The being who is a caregiver needs to have empathy for the one who is being taken care of, ie, projecting to the existential situation of the lived moment, because care only occurs when there are signs of concern. In nursing actions on the one hand, there is the person who is ill and on the other, the professional delivering care, both bringing in own essence caring. Moreover,it is this dyad that allows nurse-patient communication in which everyone finds themselves in possibility of self-care and concern for each other.

We found in the speech of professionals that they feel pleased and happy to be with each other and feel professionally satisfied in this lived temporality. In these situations, we understand that time, experience, training and personal and professional attitude will make the care of terminally illpatients more rewarding for the routine of these professionals ${ }^{(8)}$.

Palliative care in hospital environment is an adjunctive modality of care, since homecare is seen as the basic essence of caring. However, before the exacerbation of symptoms that cannot be controlled at home, several times hospitalization of the patient becomes necessary ${ }^{(6)}$. His/her prolonged stay in the Oncology Wardas well as many admissions causes thenursing professional to be closer to the patient and interactivity to the experience in which the patient is inserted, enabling solicitude of care that go beyond professional contact with the patient and staff to transcend this caregiver that even outside the work environment, 
expresses concern for the focus of their care: the cancer patient without therapeutic possibilities.

Emotional involvement and bond formation allow a relationship of greater trust between patient, family and nursing staff. The professional realizes that this way, the treatment and care given to these beings make their pains less painful. Thus, asunderstanding the world, the being-there discovers how much he/she is with himself/ herself, and this understanding has the essential structure of the project, comprising being-there, designs not only the world as a horizon of everyday concerns, but also its power to be of concern ${ }^{(19)}$.

In Heidegger's meditation, we realize that man, while being-in-the-world is there in the world. This condition is a fact that reveals its irrevocable position, ie even in the process of opening, the being-there isalways faced with himself/herself, having been launched in the world. And in his/her surrounding world, represented by the hospital, the nurse, many times experiences the sorrows of care when dealing with terminal life. Death is a reality in daily nursing care, but the suffering is associated with what it brings, something difficult to be encompassed in the professional routine. In their speeches, the participants stated that, even suffering, the practice of nursing requires that we continue to care for others who also suffer ${ }^{(5)}$.

To provide humanized care and being-with-the-sick, the nurse has an essential tool, namely, himself. To do so, it becomes essential to transcend herself/himself, to be able to provide nursing therapeutic care to cancerpatients as a self-awareness, values clarification, exploration of feelings, sense of ethics and responsibility ${ }^{(20)}$.

A study aiming to investigate the humanization of care in the perceptions of nurses highlightedthe need for these professionals to know themselves before knowing each other and, through this self-awareness, discover their abilities and limitations in order to plan activities that allow the patient and family to also perceive them as human beings in the world of care ${ }^{(20)}$. Thus, by being-inthe-world, these professionals unveil feelings that bring in their own world (selbstwelt), considering that existing-inthe-world is, first of all, understandingthemselves in their own being.

From participants' statements, we were able to infer that working in an Oncology wardis something that causes physical and mental suffering from a feeling of powerlessness and helpless before the death-dying process. The literature confirms that this feeling of ineffectiveness of nursing professional before the biotechnical modern medicine that, increasingly, through cutting-edge technologies, seeking the inclusion of technics and researches aimed at curing, aims survival of their patients and neglect the process of terminally ill and death when theyhouse the illusion of victory over death ${ }^{(21-22)}$.
Death is seen and experienced by nursing staff as an intruder in the existence of the patient and also as a threat to the omnipotence of his/her own being, that is who is supposed to prevent this process, presenting the cure for the suffering of the patient ${ }^{(23)}$. The lack of preparation and knowledge of death is implicated as a triggering factor in occupational stress among professionals ${ }^{(18,24)}$.

When faced with death-dying, feelings of anxiety, frustration and sadness mentioned by participants are mentioned in the literature as biopsychosocial effects of the moral suffering ${ }^{(25)}$. This situation is reinforcedby the authors mention that when nurses face ethical barriersin their practical skills, they feel forced to compromise their personal and standardvalues, and may experience distress ${ }^{(26)}$. This suffering can occur as a coping response when, after a decision of ethical conflict, nurse practitioners recognize personal action hindered by individual, institutional or social impediments.

Therefore, we recognize the need for nursing professionals to be prepared to deal with terminally ill patients anddeath and do not deny care ${ }^{(18)}$, considering that this professional while caregivers can help the person in his/ her dying while having the ethical principles of palliative care as a common thread in care. These professional can even preserve the dignity of that individual and assist in coping and in recognition of his/her death. For this, it is essential to make sense of his/her own self, ie, being-there will be authentic in the care of terminally ill patients when recognize that death is a finite and inevitable process from the beginning and that the human being is predetermined to his/her end, to establish effective and humane care in terminally ill patients ${ }^{(8)}$.

This study unveiled the experience of nursing staff in caring for people with cancer in a Oncology wardof a general hospital and had some limitations resulting from being developed in a particular scenario, where nurses work without support of a palliative care multidisciplinary team. Our results cannot be generalized, but may point to the reality of many institutions and health professionals in the Brazilian scenario. We hope the findings of this study contribute to and encourage further research to understand and recognize nursing professionals as human beings deservesof care as the authentic care will only emerge in the palliative care hospital when who performs the act of caring is also recognized in care.

\section{CONCLUSION}

This study allowed us to understand, through Heidegger's existential phenomenology, the meaning and significance attributed by the palliative care by nursing professionals in the Oncological Hospital Ward. This professional as being-in-the-world, in developing their profession, have the opportunity to playtheir existing
The existence of nursing in caring for terminally ills'life: a phenomenological study Almeida CSL, Sales CA, Marcon SS 
contact in caring, becoming a being -with-others in similar experiences with other beings, cancer patients.

The triad nursing-patient-family, despite the daily difficulties, nursing professionals experience not only care, but also the joys and sorrows of caring. The feelings of joy, pleasure, well-being and satisfaction are manifested when the nursing staff experience recognition and appreciation whencaringforthose who are suffering. We also learned that the uncomfortable presence of death creates feelings of distress compared to the suffering imposed on the patient and family.

The unveiling of the experience of the nursing staff in-their-beinga caregiver in the Oncology Ward signaled facets that can contribute to reflections in the field of education, knowledge and practice of nursing. These contributions refer to the specificities and needs involved in the care of end of life. The encounter with death is part of the daily life of these professionals, arousing feelings difficult to be embraced because of the lack of preparation for working with death.

In our view, it is necessary thatleaders of healthcare institutions (re)think about this issue, subsidies should be provided through courses, workshops and discussions, so that professionals can develop their activities fully, aiming welfare of the patient and family. Thus, it is necessary that nurses are also assisted holistically and recognized as biopsychosocial and spiritual human beings, not merely as providers of care beings. Developing manuals, protocols and guides aresuggested based on the daily needs of nursing professionals to direct their care in Oncology hospital palliative care, meeting their needs and limitations.

\section{REFERENCES}

1. Sales CA, Violin MR, Santos EM, Salci MA, D’Artibale EF, Decesaro MN. Cuidados paliativos: relato de experiência de sua aplicabilidade em um projeto de extensão. Ciênc Cuid Saúde. 2009;8 Supl:125-9.

2. World Health Organization. World cancer report, 2008. Lyon: International Agency for Research on Cancer; 2009.

3. Torres-Mesa LM, Schmidt-Riovalle J, Garcia-Garcia I. Legislative knowledge and preparation of health personnel for the care process of death. Rev Esc Enferm USP [Internet]. 2013 [cited 2013 June 27];47(2)]:464-70. Available from: http:// www.scielo.br/pdf/reeusp/v47n2/en_27.pdf

4. Melo AGC, Caponemo R. Cuidados paliativos: abordagem contínua e integral. In: Santos SS. Cuidados paliativos discutindo a vida, a morte e o morrer. São Paulo: Atheneu; 2009. p. 257-67.

5. Mota MS, Gomes GC, Coelho MF, Lunardi Filho WD, Sousa LD. Reações e sentimentos de profissionais da enfermagem frente à morte dos pacientes sob seus cuidados. Rev Gaúcha Enferm. 2011;32(1):129-35.

6. Silva MM, Moreira MC. Standardization of nursing care in a palliative care oncology setting: perceptions of nurses. Acta Paul Enferm [Internet]. 2011[cited 2013 May 20]; 24(2):172-8. Available from: http://www.scielo.br/pdf/ape/v24n2/en_03.pdf

7. Gama G, Barbosa F, Vieira M. Factors influencing nurses'attitudes toward death. Int J Palliat Nurs. 2012;18(6):267-73

8. Borrell MS. Acompañar en la muerte: competencias de afrontamiento y autoeficacia. Rev Enferm. 2010;33(11):742-54.

9. Fernandes MFP, Komessu JH. Nurses' challenges in view of the pain and suffering of families of terminal patients. Rev Esc Enferm USP [Internet]. 2013 [cited 2013 June 25];47(1):250-7. Available from: http://www.scielo.br/pdf/reeusp/v47n1/en_a32v47n1.pdf
10. Brasil. Ministério da Saúde; Instituto Nacional do Câncer. Estimativa 2013: incidência de câncer no Brasil. [Internet]. Brasília; 2012 [citado 2013 jul. 04]. Disponível em: http:// www.inca.gov.br/rbc/n_57/v04/pdf/13_resenha_estimativa2012_incidencia_de_cancer_no_brasil.pdf

11. Heidegger M. Ser e tempo. 6a ed. Petrópolis: Universitária São Francisco; 2012.

12. Duarte MR, Rocha SS. As contribuições da filosofia heideggeriana nas pesquisas sobre o cuidado em enfermagem. Cogitare Enferm. 2011;16(2):361-4.

13. Josgrilberg RS. O método fenomenológico e as ciências humanas. In: Castro DSP, organizador. Fenomenologia e análise do existir. São Paulo: UMESP; 2000. p. 75-93.

14. Oliveira MHC. Estrelas refletidas nas noites globais: estudo de representações de idosos nas telenovelas da rede globo de televisão [tese doutorado]. Porto Alegre: Departamento de Comunicação Social, Pontifícia Universidade Católica do Rio Grande do Sul; 2008.

15. Silva EB. Heidegger e a destruição do conceito metafísico tradicional de existência. Inquietude [Internet]. 2012 [citado 2013 maio 20]; 3(1):54-63. Disponível em: http://www. inquietude.org/index.php/revista/article/view/112/130

16. Martins J. A ontologia de Heidegger. In: Martins J, Bicudo MAV. Estudo sobre existencialismo, fenomenologia e educação. 2a ed. São Paulo: Centauro; 2006. p. 43-56.

17. Sales CA, Silva VA. A atuação do enfermeiro na humanização do cuidado no contexto hospital. Ciênc Cuid Saúde. 2011;10(1):66-73.

18. Chan HY, Lee LH, Chan CW. The perceptions and experiences of nurses and bereaved families towards bereavement care in an oncology unit. Support Care Cancer. 2013;21(6):1551-6. 
19. Sales CA, Schuhli PAP, Santos EM, Waidman MAP, Marcon SS. Vivências dos familiares ao cuidar de um ente esquizofrênico: um enfoque fenomenológico. Rev Eletr Enferm [Internet]. 2010 [citado 2011 ago. 24];12(3):456-63. Disponível em: http://www.fen.ufg.br/revista/v12/n3/v12n3a06.htm

20. Chernicharo IM, Silva FD, Ferreira MA. Humanização no cuidado de enfermagem nas concepções de profissionais de enfermagem. Esc Anna Nery Rev Enferm. 2011;15(4):686-93.

21. Silva KS, Kruse MHL. As sementes dos cuidados paliativos: ordem do discurso de enfermeiras. Rev Gaúcha Enferm. 2009;30(2):183-9.

22. Marques IR, Souza ARS. Tecnologia e humanização em ambientes intensivos. Rev Bras Enferm. 2010;63(1):141-4.

23. Macedo ES, Marques IM, Pinheiro MM, Góes FGB. A percepção do enfermeiro frente à morte do paciente de UTI adulto. Rev Pesq Cuid Fundam Online [Internet]. 2010 [citado 2011 ago. 24];2(1):690-703. Disponível em: http://www.seer.unirio.br/ index.php/cuidadofundamental/article/view/519/pdf_7
24. Souza, KW, Reis PED, Gomes IP, Carvalho EC. Prevention strategies for testicular and penile cancer: an integrative review. Rev Esc Enferm USP [Internet]. 2011 [cited 2013 Sept 25];45(1):272-6. Available from: http://www.scielo.br/pdf/ reeusp/v45n1/en_39.pdf

25. Barlem ELD, Lunardi VL, Lunardi GL, Dalmolin GL, Tomaschewski JG. The experience of moral distress in nursing: the nurses' perception. Rev Esc Enferm USP [Internet]. 2012 [cited 2013 July 05];46(3):681-8. Available from: http://www. scielo.br/pdf/reeusp/v46n3/en_21.pdf

26. Pauly B, Varcoe C, Storch J, Newton L. Registered nurses' perceptions of moral distress and ethical climate. Nurs Ethics. 2009;16(5):561-73. 